\title{
Karakter Root Re-Growth Sebagai Parameter Toleransi Aluminium pada Tanaman Padi
}

\author{
Dewi Indriyani Roslim ${ }^{1 *}$, Miftahudin'), Utut Suharsono1), Hajrial Aswidinnoor'), dan Alex \\ Hartana ${ }^{1)}$ \\ 1)Departemen Biologi, Fakultas Matematika Ilmu Pengetahuan Alam, Institut Pertanian Bogor, \\ 2) Departemen Agronomi dan Hortikultura, Fakultas Pertanian, Institut Pertanian Bogor, \\ Kampus IPB Darmaga, Bogor 16680
}

Diterima 04-12-2009 Disetujui 11-04-2010

\begin{abstract}
Aluminum ( $\mathrm{Al})$ is one of the major limited factors in crop production on acid soils. Aluminum tolerant plants can be selected from plant breeding program by one of the physiological parameters representing Al tolerance character, such as root re-growth capability during recovery from the Al-stress. In this study we determined the concentration and time exposure of $\mathrm{Al}$ stress that was able to differentiate the response of three local upland rice varieties (Grogol, Hawarabunar and Krowal) and an Al-sensitive rice variety (IR64) to Al-stress, and evaluated the effectiveness of root re-growth (RRG) characters as an Al tolerance parameter in rice. The study consisted of three experiments, which were 1) nutrient culture experiment with different Al concentration treatments in growth chamber, 2) pot experiment in greenhouse using Jasinga yellow red podzolic acid soil containing 26,66 me/100 $\mathrm{g} \mathrm{Al}$ and $\mathrm{pH} \mathrm{4,6} \mathrm{as}$ planting media, and 3) phenotyping of F2 population using RRG character. The results showed that Al treatment at $15 \mathrm{ppm}$ for $\mathbf{7 2} \mathrm{h}$ was able to distinctly differentiate between Al-tolerant (Grogol and Hawarabunar) and Al-sensitive varieties (Krowal and IR64). Planting of the rice varieties on acid soils showed similar result as that of the nutrient culture. Phenotyping of F2 population using RRG character indicated the existence of RRG value variation. These variations demonstrated that RRG character can be used as an Al tolerance parameter in rice and therefore can be effectively applied to screen rice $\mathrm{F} 2$ population that segregate to Al tolerance character.
\end{abstract}

Keywords: aluminum tolerance, rice, root re-growth, tolerance parameter

\section{PENDAHULUAN}

Aluminium (Al) merupakan salah satu faktor pembatas utama produksi tanaman pada tanah asam karena Al dapat menjadi racun bagi tanaman. Keracunan akibat kandungan Al yang tinggi pada tanah asam dapat diperbaiki dengan pengapuran, namun tindakan ini tidak praktis dan membutuhkan biaya tinggi. Pendekatan alternatif yang mungkin dilakukan adalah menggunakan genotipe-genotipe tanaman yang mempunyai toleransi yang tinggi terhadap cekaman Al. Beberapa genotipe padi lokal asal Indonesia diketahui bersifat toleran Al (Khatiwada et al., 1996). Penapisan terhadap 150 varietas padi lokal Indonesia oleh Asfaruddin (1997), Farid (1997), dan Syakhril (1997), yaitu dengan menanam semua varietas padi di tanah asam dengan $\mathrm{pH}$ 4,9, kelarutan Al 2,6 me/100 g dan kejenuhan Al sekitar $70 \%$, menunjukkan adanya beberapa varietas

\footnotetext{
Telp: +622518622833

Email: miftahudin@ipb.ac.id
}

yang tergolong toleran (Grogol, Hawarabunar, Jambu \& Seratus Malam) dan sensitif Al (Jatiluhur, Krowal, Randah Padang \& Sirumbia).

Penanaman di tanah asam dengan kandungan Al tinggi untuk menapis plasma nutfah padi merupakan salah satu cara untuk mengidentifikasi derajat toleransi Al tanaman padi. Namun demikian, uji lapang ini membutuhkan areal yang luas, dan membutuhkan banyak tenaga dan waktu yang lama untuk memperolah data, karena pengamatan dilakukan sampai tanaman dewasa dan berproduksi. Oleh karena itu perlu suatu metode yang efisien dan cepat yaitu pengamatan pada fase awal pertumbuhan tanaman atau fase kecambah. Metode yang biasa digunakan adalah metode kultur hara (Zhang et al., 2004). Melalui metode kultur hara, banyak peubah yang dapat digunakan sebagai parameter toleransi $\mathrm{Al}$, seperti panjang akar relatif (PAR), pemanjangan akar relatif (relative root elongation 
$=\mathrm{RRE}$ ), dan pertumbuhan kembali akar (root re-growth $=\mathrm{RRG}$ ) setelah tanaman mendapat perlakuan cekaman Al. Peubah PAR dan RRE digunakan oleh Suparto, (1999) untuk mengevaluasi 20 varietas padi hasil penapisan di lapang (Asfaruddin, 1997; Farid, 1997; Syakhril, 1997). Hasil uji menggunakan metode kultur hara dengan peubah PAR ini menunjukkan bahwa beberapa varietas padi menampakan hasil yang berbeda antara hasil uji lapang dan kultur hara.

Terdapat kelemahan dari karakter PAR sebagai parameter toleransi Al pada tanaman padi, yaitu ketidakkonsistenan antara hasil uji lapang dengan kultur hara dan kesulitan untuk mencari akar kecambah padi yang seragam sebelum perlakuan Al. Kelemahan lain, peubah PAR hanya dapat diterapkan pada populasi yang seragam secara genetik seperti galur inbred rekombinan ( $\mathrm{RIL}=$ recombinant inbred lines) atau galur mendekati isogenik ( $\mathrm{NIL}=$ near isogenic lines), karena penentuan nilai PAR memerlukan data panjang akar baik dari kecambah padi yang ditumbuhkan pada media kontrol (tanpa Al) dan perlakuan cekaman Al. Pada populasi segregasi seperti populasi F2 memerlukan pengukuran parameter toleransi Al pada tiap individu tanaman yang secara genetik berbeda dan tidak memungkinkan dibuat perlakuan pembanding tanpa cekaman Al (kontrol). Oleh karena itu perlu dicari metode penentuan parameter toleransi Al yang dapat diaplikasikan pada tiap individu dari populasi segregasi tersebut.

Salah satu karakter yang sudah digunakan untuk mengamati sifat toleransi Al pada populasi segregasi adalah karakter RRG. Karakter RRG ini telah digunakan pada tanaman Triticale (Zhang et al., 1999) dan rye (Secale cereale L.) (Miftahudin et al., 2004) untuk menentukan sifat toleransi Al pada tiap individu populasi segregasi F2 dan silang balik (backcross). Pada tanaman rye, apabila individu tanaman memiliki nilai RRG kurang dari $2,5 \mathrm{~cm}$, maka tanaman tersebut tergolong sensitif Al, sebaliknya apabila individu tanaman yang memiliki nilai RRG lebih besar atau sama dengan $2,5 \mathrm{~cm}$, maka digolongkan ke dalam tanaman toleran Al.

Parameter RRG didasarkan pada kemampuan suatu akar tanaman untuk tumbuh kembali secara normal setelah mendapat perlakuan cekaman Al. Nilai RRG ditentukan dengan cara mengukur panjang akar utama pada saat pemulihan setelah tanaman mendapat perlakuan cekaman Al selama waktu tertentu. Akar tanaman yang toleran Al akan sedikit atau sama sekali tidak mengalami kerusakan ketika mendapat cekaman Al dibanding akar tanaman yang sensitif Al (Delhaize et al., 2004; Liao et al., 2006), Sehingga akar tanaman toleran Al akan memiliki kemampuan pertumbuhan akar kembali yang lebih tinggi dibanding akar tanaman sensitif Al. Hingga saat ini belum ada yang melaporkan mengenai penggunaan karakter $R R G$ sebagai parameter toleransi Al pada tanaman padi. Oleh karena itu, penelitian ini bertujuan untuk 1) menentukan konsentrasi dan periode cekaman Al yang tepat untuk dapat membedakan respon penghambatan pertumbuhan akar antara varietas yang toleran Al dan sensitif Al; dan 2) mengevaluasi efektifitas karakter RRG sebagai parameter sifat toleransi Al pada padi.

\section{BAHAN DAN METODE}

Bahan Tanaman. Bahan tanaman yang digunakan adalah benih padi dari 3 varietas padi gogo lokal Indonesia (Grogol, Hawarabunar \& Krowal) dan varietas IR64 serta populasi F2 hasil persilangan IR64 dengan Hawarabunar. Benih padi diperoleh dari Balai Penelitian Tanaman Padi Muara, Bogor, Jawa Barat.

Analisis Root Re-Growth (RRG) I. Analisis RRG bertujuan untuk menentukan konsentrasi dan periode cekaman Al serta karakter fisiologis yang tepat sebagai respon tanaman padi terhadap cekaman Al. Analisis RRG dilakukan dengan metode kultur hara di dalam ruang tumbuh (growth chamber) dengan suhu $29^{\circ} \mathrm{C}-31^{\circ} \mathrm{C}$ dan pencahayaan 300 PPFD (photo proton flux density) selama 12 jam setiap hari. Benih padi direndam dalam larutan khloroks 5,25\% selama 15 menit. Setelah dicuci dengan air destilata, biji direndam selama 24 jam dalam air destilata pada suhu ruang dan keadaan gelap. Selanjutnya benih dikecambahkan pada kertas merang lembab selama 3 hari pada suhu ruang. Benih-benih yang berkecambah dipilih sebanyak 10 kecambah per varietas yaitu yang memiliki panjang akar $\pm 1 \mathrm{~cm}$. Benih tersebut lalu ditanam pada jaring plastik yang diapungkan di atas larutan hara minimal modifikasi dari Miftahudin et al., (2002), pada pH 4,0 \pm 0,02 selama 24 jam. Kemudian kecambah ditumbuhkan pada larutan hara yang mendapat perlakuan 0 (kontrol), 45 dan 60 ppm Al selama 24 jam. Selanjutnya kecambah ditumbuhkan pada larutan hara tanpa $\mathrm{Al}$ selama 48 jam (disebut masa pemulihan pertumbuhan 
akar). Pengukuran panjang akar dilakukan pada saat akhir perlakuan cekaman Al dan pada saat akhir masa pemulihan. Nilai RRG diperoleh dengan cara menghitung selisih panjang akar pada akhir pemulihan dengan panjang akar pada saat akhir perlakuan Al. Selain RRG, dilakukan juga analisis penghambatan pertumbuhan akar (PPA) dan panjang akar relatif (PAR) sebagai pembanding RRG. Persen penghambatan pertumbuhan akar dihitung dengan rumus sebagai berikut:

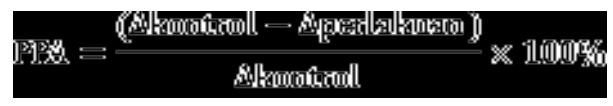

dimana $\Delta$ perlakuan: selisih panjang akar sesudah dan sebelum cekaman Al pada setiap perlakuan; $\Delta$ kontrol: selisih panjang akar pada periode antara sesudah dan sebelum cekaman Al pada kontrol. Panjang akar relatif (PAR) dihitung dengan rumus sebagai berikut:

$\mathrm{PAR}=\frac{\text { panjang akar setelah cekaman Al pada perlakuan }}{\text { panjang akar setelah perionde cekaman Al pada kontrol }} \times 100 \%$

Analisis Root Re-Growth (RRG) II. Analisis RRG II dilakukan sama seperti analisis RRG I, tetapi perlakuan cekaman Al diberikan dengan konsentrasi dan periode yang berbeda, yaitu sebesar 0 (kontrol), 9, 12, dan 15 ppm Al pada $\mathrm{pH}$ 4,0 00,02 selama 72 jam. Pada analisis RRG II juga dilakukan pengamatan terhadap peubah PPA dan PAR.

Uji Toleransi Aluminium pada Tanah Asam dengan Kandungan Aluminium Tinggi. Tahapan ini dilakukan untuk verifikasi hasil percobaan kultur hara. Padi varietas Grogol, Hawarabunar, Krowal dan IR64 yang digunakan dalam penelitian ini kemudian ditanam di rumah kaca secara gogo dalam pot berdiameter $31 \mathrm{~cm}$ dan tinggi $22 \mathrm{~cm}$ dengan media tanah asam Podsolik Merah Kuning ( $\mathrm{pH} \mathrm{4,6;} \mathrm{kelarutan} \mathrm{Al}$ 26,66 me/100g) dari Gajruk, Jasinga,Bogor, Jawa Barat. Respon tanaman berupa kerusakan daun diamati pada hari ke-45 sejak tanam dan kemampuan setiap varietas menghasilkan anakan produktif atau memproduksi biji pada saat panen.

Analisis RRG pada Populasi F2. Analisis RRG pada populasi F2 bertujuan untuk menguji efektifitas karakter RRG pada populasi segregasi. Analisis RRG pada 153 kecambah dari populasi F2 hasil persilangan IR64 dan Hawarabunar dilakukan dengan mengukur panjang akar tiap kecambah yang telah mendapat perlakuan cekaman Al sebesar 15 ppm selama 72 jam dan diikuti masa pemulihan selama 48 jam.
Analisis Data. Data kuantitatif pada Analisis RRG I dan II dianalisis menggunakan Analisis Ragam berdasarkan Rancangan Acak Kelompok menggunakan program SPSS versi 15,0. Perbedaan di antara perlakuan diuji menggunakan Duncan Multiple Range Test (DMRT) pada $\mathrm{P}=0.05$. Segregasi karakter $\mathrm{RRG}$ pada populasi F2 dianalisis menggunakan Uji KhiKuadrat pada $\mathrm{P}=0.05$.

\section{HASIL DAN PEMBAHASAN Karakter Root Re-Growth sebagai Parameter} Toleransi Aluminium pada Padi. Terdapat perbedaan nilai RRG, PPA dan PAR pada keempat varietas yang diuji, akan tetapi semua varietas yang diuji, baik yang toleran maupun sensitif $\mathrm{Al}$, mengalami penghambatan pertumbuhan akar yang sangat besar selama perlakuan cekaman 45 dan 60 ppm Al yaitu 70\% sampai 90\% (Tabel 1). Idealnya untuk pengamatan respon pertumbuhan akar padi terhadap cekaman Al, hanya varietas yang sensitif Al yang akan mengalami penghambatan pertumbuhan akar e" $50 \%$ sedangkan varietas toleran Al kurang dari 50\% (Khatiwada et al., 1996). Telah diketahui bahwa varietas Hawarabunar merupakan varietas yang toleran AI (Silitonga, 2008) dan IR64 sensitif Al (Nguyen et al., 2003). Oleh karena itu, dalam perlakuan cekaman Al, diharapkan bahwa varietas yang toleran Al tidak akan mengalami penghambatan pertumbuhan akar yang sangat besar yaitu sampai di atas $70 \%$ sama dengan varietas yang sensitif Al. Berdasarkan hal tersebut, maka hasil penelitian ini mengindikasikan bahwa tingkat cekaman Al sebesar 45 dan 60 ppm terlalu tinggi untuk tanaman padi, sehingga pada tingkat cekaman tersebut karakter

Tabel 1. Rata-rata root re-growth (RRG), penghambatan pertumbuhan akar (PPA) dan panjang akar relatif (PAR) pada empat varietas padi dan pada perlakuan 0, 45 dan 60 ppm Al selama 24 jam diikuti masa pemulihan selama 48 jam.

\begin{tabular}{llll}
\hline Faktor & RRG $(\mathrm{cm})$ & PPA $(\%)$ & PAR $(\%)$ \\
\hline
\end{tabular}

Varietas

Grogol $\quad 2,46 \pm 0,26^{a} 76,18 \pm 3,19^{a} 89,49 \pm 10,18^{a}$

Hawarabunar $\quad 3,21 \pm 0,18^{\mathrm{b}} 75,65 \pm 3.80^{\mathrm{a}} 83,30 \pm 11,88^{\mathrm{a}}$

IR64 $\quad 1,99 \pm 0,18^{\mathrm{c}} 87,74 \pm 1,75^{\mathrm{b}} 61,58 \pm 8,14^{\mathrm{b}}$

Krowal $\quad 1,05 \pm 0,20^{d} 89,67 \pm 1,97^{b} 81,51 \pm 3,58^{a}$

Konsentrasi Al (ppm)

\begin{tabular}{c}
$45 \quad 2,33 \pm 0,20^{\mathrm{a}} 79,74 \pm 3.68^{\mathrm{a}} 80,35 \pm 8,35^{\mathrm{a}}$ \\
$60 \quad 2,03 \pm 0,20^{\mathrm{a}} 84,88 \pm 1,67^{\mathrm{b}} 77,59 \pm 8,54^{\mathrm{a}}$ \\
\hline $\begin{array}{l}\text { Keterangan: angka pada kolom yang sama yang diikuti oleh huruf } \\
\text { yang sama tidak berbeda nyata pada uji DMRT á }= \\
0,05\end{array}$
\end{tabular}


RRG maupun PAR tidak dapat ditentukan dan digunakan sebagai parameter toleransi Al pada padi.

Terjadinya penghambatan pertumbuhan akar yang besar selama cekaman Al didukung oleh data pada pengamatan morfologi akar tanaman bahwa perlakuan cekaman pada tingkat 45 dan 60 ppm Al menyebakan akar-akar dari varietas toleran dan sensitif Al menjadi tebal, kaku, dan pendek. Selain itu akar lateral baik pada varietas toleran maupun sensitif Al tidak berkembang dengan baik (Gambar 1). Fenomena ini menunjukkan bahwa cekaman Al yang tinggi dapat merusak sistem perakaran tanaman padi. Hal ini terjadi karena pada $\mathrm{pH}$ di bawah 5,0, Al berada dalam bentuk $\mathrm{Al}^{3+}$ yang sangat toksik bagi akar tanaman, terutama pada daerah 0,5-5 mm dari ujung akar yang meliputi zona meristem dan pemanjangan akar, sehingga daerah ini akan mengalami penebalan dan akar tumbuh lebih pendek. Hasil penelitian cekaman Al pada tanaman padi varietas Taichung Native 1 menunjukkan bahwa semakin tinggi cekaman Al pertumbuhan akar semakin terhambat (Wang \& Kao, 2004). Oleh karena tingkat cekaman 45 dan 60 ppm Al selama 24 jam tidak dapat digunakan sebagai kondisi yang tepat untuk membedakan respon varietas padi toleran dan sensitif

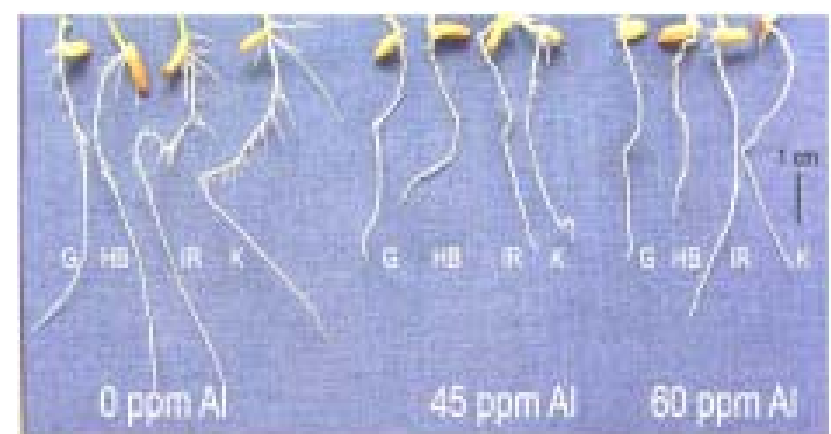

Gambar 1. Profil akar empat varietas padi setelah perlakuan 0, 45 dan 60 ppm Al selama 24 jam. G: Grogol, HB: Hawarabunar, IR: IR64, K: Krowal. Bar $=1 \mathrm{~cm}$.
Karakter root re-growth sebagai parameter

Al, maka dilakukan percobaan kedua dengan menurunkan tingkat cekaman Al pada konsentrasi yang lebih rendah.

Bagian kedua dari penelitian dilakukan pada konsentrasi Al yang lebih rendah dari Analisis RRG I. Sebelum dilakukan Analisis RRG II telah dilakukan percobaan pendahuluan dengan memberikan perlakuan cekaman 3 dan 6 ppm Al selama 72 jam diikuti 48 jam masa pemulihan. Hasil percobaan pendahuluan ini menunjukkan kedua konsentrasi Al tersebut tidak dapat membedakan respon pertumbuhan akar antara tanaman padi toleran dan sensitif $\mathrm{Al}$ (data tidak disajikan). Oleh karena itu dilakukan Analisis RRG II dengan cekaman 0, 9, 12 dan 15 ppm Al selama 72 jam dan diikuti 48 jam masa pemulihan.

Pada analisis RRG II ini hanya varietas sensitif $\mathrm{Al}$ (IR64 \& Krowal) yang mengalami penghambatan pertumbuhan akar cukup besar selama perlakuan cekaman pada ketiga konsentrasi Al tersebut, yang ditunjukkan oleh nilai PPA keduanya di atas $60 \%$. Akan tetapi tidak terdapat perbedaan nyata nilai RRG baik pada varietas toleran maupun sensitif Al pada ketiga tingkat cekaman Al (9, 12 dan 15 ppm) (Tabel 2). Hasil ini mengindikasikan bahwa perlakuan cekaman dengan kisaran konsentrasi Al sebesar 9 sampai 15 ppm selama 72 jam dan diikuti masa pemulihan selama 48 jam pada analisis RRG II ini sudah cukup memberikan respon penghambatan akar yang besar pada varietas sensitif Al tetapi tidak terlalu menghambat pertumbuhan akar dari varietas toleran Al.

Berdasarkan karakter PAR, terlihat perbedaan nyata di antara varietas toleran dan sensitif Al pad tingkat cekaman 9-15 ppm Al selam 72 jam, tetapi nilai PAR dari varietas yang sensitif Al berada di atas $50 \%$. Oleh karena itu, pada kisaran tingkat cekaman

Tabel 2. Rata-rata root re-growth (RRG), penghambatan pertumbuhan akar (PPA) dan panjang akar relatif (PAR) pada 4 varietas padi dan pada perlakuan $0,9,12$ dan 15 ppm Al selama 72 jam diikuti masa pemulihan selama 48 jam.

\begin{tabular}{|c|c|c|c|c|c|c|c|c|c|c|c|c|}
\hline \multirow[b]{2}{*}{ Varietas } & \multicolumn{4}{|c|}{$\mathrm{RRG}(\mathrm{cm})$} & \multicolumn{4}{|c|}{ PPA (\%) } & \multicolumn{4}{|c|}{ PAR (\%) } \\
\hline & & & & & & & & & & & & \\
\hline Grogol & 2,78 & \pm & 0,13 & a & 45,03 & \pm & 3,04 & a & 72,90 & \pm & 2.13 & ab \\
\hline Hawarabunar & 2,87 & \pm & 0,37 & a & 54,91 & \pm & 6,70 & $\mathrm{~b}$ & 80,31 & \pm & 14,48 & a \\
\hline IR64 & 0,60 & \pm & 0,05 & $\mathrm{~b}$ & 68,40 & \pm & 2,08 & c & 61,38 & \pm & 10,14 & c \\
\hline Krowal & 0,59 & \pm & 0,21 & $\mathrm{~b}$ & 61,16 & \pm & 10,25 & $\mathrm{~b}$ & 64,96 & \pm & 6,30 & $\mathrm{bc}$ \\
\hline \multicolumn{13}{|l|}{ Konsentrasi Al (ppm) } \\
\hline 9 & 1,90 & \pm & 0,29 & a & 51,85 & \pm & 3,86 & a & 73,79 & \pm & 8,30 & a \\
\hline 12 & 1,62 & \pm & 0,19 & a & 58,45 & \pm & 6,41 & $\mathrm{~b}$ & 68,99 & \pm & 8,59 & a \\
\hline 15 & 1,62 & \pm & 0,09 & ${ }^{a}$ & 61,83 & \pm & 6,29 & ${ }^{b}$ & 66,88 & \pm & 7,89 & ${ }^{a}$ \\
\hline
\end{tabular}


tersebut, karakter PAR tidak dapat digunakan sebagai parameter toleransi Al pada padi.

Pengamatan dampak keracunan Al terhadap morfologi akar dari keempat varietas padi menunjukkan bahwa pada perlakuan Al sebesar 15 ppm selama 72 jam sangat menghambat pertumbuhan akar utama dan akar adventif dari varietas sensitif Al serta menyebabkan ketidakmampuan pemulihan pada beberapa tanaman yang diuji. Sebaliknya pada varietas toleran Al, pada saat cekaman maupun pemulihan, akar utama dan akar adventif masih dapat tumbuh dengan baik (Gambar 2). Padi merupakan spesies tanaman serealia yang paling toleran terhadap cekaman Al (Kim et al., 2001). Meskipun variasi genotipe terjadi di dalam spesies padi (Ma et al., 2002), tetapi perbedaan respon terhadap cekaman Al antara varietas toleran dan sensitif Al sering tidak dapat diamati secara jelas. Pada jagung, konsentrasi Al sebesar 1,35 ppm selama 5 menit sudah cukup untuk menghambat pembelahan sel pada meristem proksimal akar dan menyebabkan pertumbuhan abnormal pada akar lateral dari varietas yang sensitif (Doncheva et al., 2005). Oleh karena itu konsentrasi Al dan periode cekaman Al yang tepat untuk menguji toleransi suatu varietas padi terhadap cekaman Al sangat menentukan. Untuk analisis selanjutnya perlakuan cekaman Al yang diberikan sebesar 15 ppm selama 72 jam karena pada tingkat cekaman Al sebesar 15 ppm sebagian besar akar dari tanaman sensitif Al tidak mampu pulih kembali.

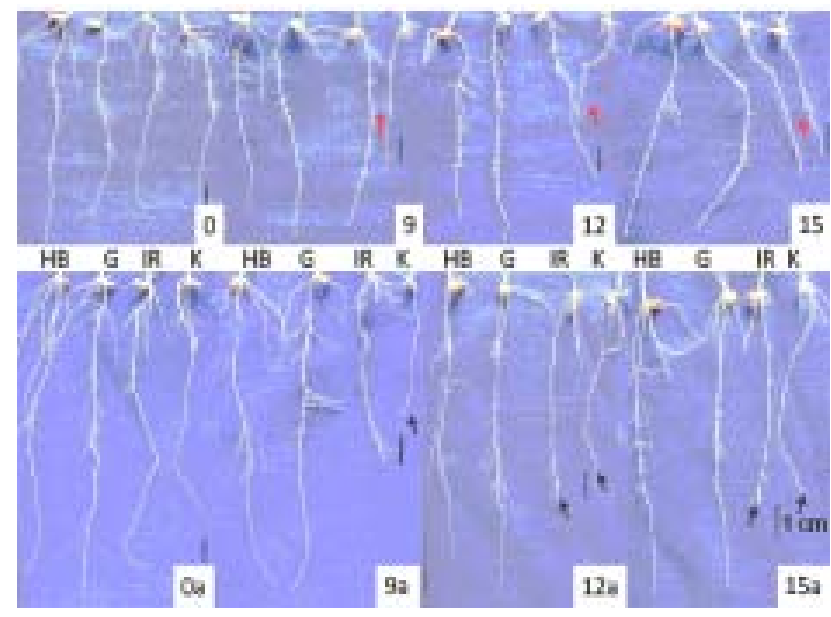

Gambar 2. Profil akar empat varietas padi setelah perlakuan cekaman Al sebesar 9, 12 dan 15 ppm selama 72 jam diikuti 48 jam pemulihan (9a, 12a, 15a). G: Grogol, HB: Hawarabunar, IR: IR64, K: Krowal, '!: pertumbuhan akar lateral dari IR64 dan Krowal sangat terhambat saat tercekam Al selama 72 jam, '!: akar utama tidak dapat tumbuh kembali pada masa pemulihan. Bar $=1 \mathrm{~cm}$.
Uji Toleransi Tanaman Padi pada Tanah Asam dengan Kandungan Aluminium Tinggi. Untuk menguji kesesuaian hasil Analisis RRG II dengan sifat toleransi Al pada padi dilakukan uji toleransi Al dengan menanam keempat varietas padi di tanah asam dengan kandungan Al tinggi. Uji toleransi di tanah Al ini memberikan hasil yang sejalan dengan hasil Analisis RRG II dan membuktikan bahwa varietas Grogol dan Hawarabunar tergolong varietas toleran Al, sedangkan varietas IR64 dan Krowal tergolong varietas sensitif Al. Pada pengamatan hari ke-45 setelah tanam, terlihat bahwa varietas IR64 mengalami kerusakan daun paling parah disusul varietas Krowal. Gejala sekunder dari keracunan Al pada penelitian ini tampak nyata pada varietas IR64 yaitu dari adanya kerusakan daun yang dimulai dari menguningnya ujung daun (Gambar 3). Selanjutnya daun yang menguning berubah menjadi merah atau coklat pada seluruh helaian daun, hingga daun mulai layu dan mati. Pengamatan pada saat fase reproduktif menunjukkan bahwa varietas Grogol dan Hawarabunar mengalami penurunan jumlah anakan produktif berturut-turut sebesar $50 \%$ dan $25 \%$, sedangkan IR64 mengalami penurunan jumlah anakan produktif cukup drastis yaitu sebesar $67 \%$ dari kontrol, bahkan varietas Krowal tidak mampu menghasilkan anakan produktif.

Sejak awal pertumbuhannya, tanaman selalu dihadapkan pada berbagai cekaman, baik cekaman biotik (serangan hama, penyakit dan gulma) maupun cekaman abiotik (kekeringan, kadar garam tinggi, logam

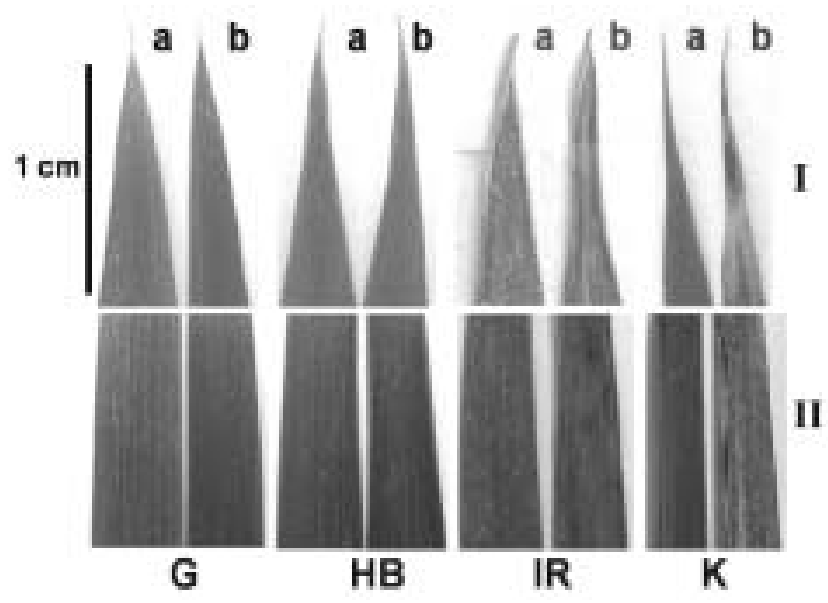

Gambar 3. Gejala sekunder akibat keracunan Al pada empat varietas padi yang diamati pada hari ke-45 setelah ditanam di tanah sawah (a) dan Al (b). G: Grogol, HB: Hawarabunar, IR: IR64, K: Krowal, a: kontrol, b: perlakuan tanah $\mathrm{Al}$, I: panjang daun $1 \mathrm{~cm}$ pada posisi $1 \mathrm{~cm}$ dari ujung daun, II: panjang daun $1 \mathrm{~cm}$ pada posisi $4 \mathrm{~cm}$ dari ujung daun. Bar $=1 \mathrm{~cm}$. 
berat, suhu tinggi maupun rendah, dan tanah asam). Pada tanah asam, tanaman dapat mengalami keracunan Al yang merupakan faktor utama pembatas produksi tanaman pertanian (Samac \& Tesfaye, 2003). Produksi atau hasil merupakan karakter agronomi yang penting dan dapat diukur dari jumlah anakan produktif yang mampu dihasilkan oleh suatu tanaman padi. Varietas yang toleran Al tidak mengalami penurunan jumlah anakan secara signifikan dibandingkan varietas yang sensitif Al (Asfarudin, 1997). Hasil verifikasi pada penelitian ini sejalan dengan yang pernah dilaporkan oleh Asfaruddin (1997), Farid (1997) dan Syakhril (1997) bahwa rata-rata jumlah anakan produktif varietas Hawarabunar dan Grogol yang ditanam pada kondisi Al tinggi tidak berbeda nyata dengan jika ditanam pada Al rendah, sedangkan pada varietas IR64 dan Krowal terjadi penurunan yang signifikan.

Analisis RRG pada Populasi F2. Hasil analisis RRG dan uji toleransi Al pada tanah asam dengan kandungan $\mathrm{Al}$ tinggi menunjukkan adanya hubungan yang erat antara nilai RRG dengan sifat toleransi $\mathrm{Al}$ dari keempat varietas yang diuji. Varietas Grogol dan Hawarabunar mempunyai nilai RRG yang tinggi dan keduanya bersifat toleran $\mathrm{Al}$, sebaliknya varietas IR64 dan Krowal memiliki nilai $R R G$ yang rendah dan keduanya bersifat sensitif Al. Untuk menentukan efektifitas dari karakter RRG sebagai parameter toleransi Al, maka telah dilakukan phenotyping dengan karakter RRG pada populasi F2 hasil persilangan dari IR64 dengan Hawarabunar sebagai tetua.

Hasil analisis RRG pada populasi F2 menunjukkan bahwa nilai RRG dari setiap individu F2 bervariasi dan menyebar di antara nilai RRG kedua tetuanya (Gambar 4). Melalui analisis pada populasi F2 ini ditentukan batas toleransi Al pada tanaman padi berdasarkan karakter RRG, yaitu dengan mengamati rata-rata nilai RRG dari kedua tetua.

Rata-rata nilai $R R G$ pada tetua toleran $\mathrm{Al}$ (Hawarabunar) sebesar 2,9 $\pm 0,5 \mathrm{~cm}$ dan sensitif $\mathrm{Al}$ (IR64) sebesar 1,3 $\pm 0,4 \mathrm{~cm}$. Kisaran nilai RRG pada tetua toleran Al sebesar 2,2-3,7 cm dan sensitif $\mathrm{Al}$ sebesar 0,0-2,1 cm. Berdasarkan batas bawah nilai RRG dari tetua toleran Al dan batas atas dari tetua sensitif Al telah ditentukan bahwa setelah pemberian perlakuan cekaman Al sebesar 15 ppm selama 72 jam dan diikuti masa pemulihan selama 48 jam maka batas toleransi Al berdasarkan nilai RRG pada padi adalah $2,10 \mathrm{~cm}$. Individu yang memiliki nilai $R R G<2,10 \mathrm{~cm}$ digolongkan ke dalam sensitif $\mathrm{Al}$, sedangkan individu yang mempunyai nilai RRG e" 2,10 cm termasuk toleran Al.

Nilai RRG pada 153 kecambah F2 yang diteliti menunjukkan hasil yang bervariasi, yaitu 124 kecambah menampilkan nilai RRG seperti IR64 dan 29 kecambah lainnya seperti Hawarabunar. Uji Khi-Kuadrat terhadap data RRG pada populasi $F 2$ ini menunjukkan bahwa segregasi sifat toleransi Al berdasarkan karakter RRG ini tidak mengikuti pola pewarisan gen tunggal $\left(c_{3: 1}^{2}\right.$ hitung $=420,25 ; c_{3: 1}^{2}$ tabel $\left.=3,841 ; d f=1 ; p=0,05\right)$. Pengujian segregasi karakter RRG dengan mengikuti pola pewarisan epistasis dihibrid, menunjukkan bahwa karakter RRG juga tidak mengikuti pola pewarisan dua gen $\left\{9: 7\left(c^{2}{ }_{9: 7}=160,40 ; c^{2}{ }_{9: 7 \text { tabel }}=3,841 ; d f=1 ; p=\right.\right.$ $0,05), 13: 3\left(c^{2}{ }_{13: 3}=28,10 ; c^{2}{ }_{13: 3 \text { tabel }}=3,841 ; d f=1 ; p=\right.$ $0,05)$ dan $15: 1\left(c^{2}{ }_{15: 1}=2263,13 ; c^{2}{ }_{15: 1 \text { tabel }}=3,841 ; d f=1\right.$; $p=0,05)\}$. Hasil analisis berdasarkan pola sebaran kelas karakter RRG pada populasi F2 menunjukkan sebaran normal dengan rata-rata $1,50 \mathrm{~cm}$ dan standar deviasi 0,65 . Data sebaran nilai RRG pada populasi F2 bersifat kontinu tetapi condong ke arah tetua yang sensitif Al (Gambar 4). Berdasarkan hasil pengujian tersebut di atas maka disimpulkan bahwa karakter RRG pada tanaman padi merupakan karakter poligenik. Hasil ini sejalan dengan hasil penelitian Zhang et al., (1999) bahwa karakter RRG dapat digunakan sebagai parameter toleransi AI pada Triticale dan dikendalikan oleh banyak gen (poligen). Hasil penelitian ini juga menunjukkan bahwa karakter RRG dapat digunakan sebagai parameter toleransi Al pada padi dan secara efektif dapat diterapkan untuk menentukan sifat toleransi Al dari tiap individu tanaman pada populasi segregasi F2.

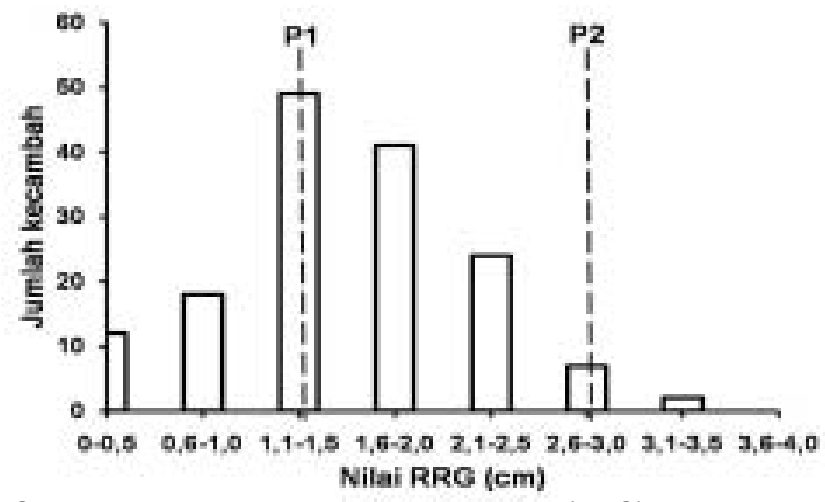

Gambar 4. Kurva sebaran nilai root re-growth (RRG) pada populasi F2 dari persilangan tetua sensitif Al (P1: IR64) dan toleran Al (P2: Hawarabunar), setelah perlakuan cekaman Al sebesar 15 ppm selama 72 jam diikuti pemulihan selama 48 jam. 


\section{KESIMPULAN}

Karakter root re-growth (RRG) dapat dijadikan sebagai parameter toleransi Al pada tanaman padi. Perlakuan cekaman Al dapat diberikan pada konsentrasi sebesar 15 ppm selama 72 jam dan diikuti 48 jam masa pemulihan. Penanaman varietas padi yang diuji pada tanah asam dengan kandungan Al tinggi juga menunjukkan hasil yang sama dengan hasil analisis RRG bahwa Grogol dan Hawarabunar termasuk varietas toleran Al, sedangkan IR64 dan Krowal termasuk varietas sensitif Al. Karakter RRG dapat digunakan untuk mengetahui sifat toleransi Al pada tiap individu tanaman pada populasi segregasi F2.

\section{UCAPAN TERIMA KASIH}

Penelitian ini dibiayai oleh Proyek Hibah Bersaing XIV Perguruan Tinggi a.n. Dr. Ir. Miftahudin, M.Si. dengan judul "Analisis Gen-gen Potensial Toleran Aluminium pada Padi” No Kontrak: 012/SP2H/PP/DP2M/III/2007, 29 Maret 2007. Penulis mengucapkan terima kasih kepada Pimpinan Balai Penelitian dan Pengembangan Tanaman Padi, Muara, Bogor.

\section{DAFTAR PUSTAKA}

Asfaruddin. 1997. Evaluasi Ketenggangan Varietas-varietas padi gogo terhadap keracunan aluminium dan efisiensinya dalam penggunaan kalium. Tesis Pascasarjana. Bogor: Institut Pertanian Bogor.

Delhaize, E., Ryan, P.R., Hebb, D.M., Yamamoto, Y., Sasaki, T. \& Matsumoto, H. 2004. Engineering high level aluminum tolerance in barley with the ALMT1 gene. PNAS 101(42): 15249-15254.

Doncheva, S., Amenos, M., Poschenrieder, C. \& Barcelo, J. 2005. Root cell patterning: a primary target for alumunium toxicity in maize. J of Exp Bot 56(414): 1213-1220.

Farid, N. 1997. Pengujian Plasma Nutfah Padi Gogo untuk ketenggangan terhadap tanah masam dan ketahanan terhadap penyakit blas. Tesis Pascasarjana. Bogor: Institut Pertanian Bogor.
Khatiwada, S.P., Senadhira, D., Carpena, A.L., Zeigler, R.S. \& Fernandez, P.G. 1996. Variability and genetics of tolerance for aluminum toxicity in rice (Oryza sativa L.). Theor Appl Genet 93:738-744.

Kim, B.Y., Baier, A.C., Somers, D.J. \& Gustafson, J.P. 2001. Aluminum tolerance in triticale, wheat and rice. Euphytica 120: 329-337.

Liao, H., Wan, H., Shaff, J., Wang, X., Yan, X. \& Kochian, V.L. 2006. Phosphorus and aluminum interactions in soybean in relation to aluminum tolerance. Exudation of specific organic acids from different regions of the intact root system. Plant Physiol 141: 674-684.

Ma, Q., Rengel, Z. \& Kuo, J. 2002. Short Communication: Aluminium toxicity in rye (Secale cereale): root growth and dynamics of cytoplasmic $\mathrm{Ca}^{2+}$ in intact root tips. Annals of Bot 89: 241-244.

Miftahudin, Scoles, G.J. \& Gustafson, J.P. 2002. AFLP markers tightly linked to the aluminum-tolerance gene Alt3 in rye (Secale cereale L.). Theor Appl Genet 104: 626-631.

Miftahudin, Scoles, G.J. \& Gustafson, J.P. 2004. Development of PCR-based co-dominant markers falnking the Alt3 gene in rye. Genome 47: 231-238.

Nguyen, B.D., Brar, D.S., Bui, B.C., Nguyen, T.V., Pham, L.N. \& Nguyen, H.T. 2003. Identification and mapping of the QTL for aluminum tolerance introgressed from the new source, Oryza rufipogon Griff., into indica rice (Oryza sativa L.). Theor Appl Genet 106: 583-593.

Samac, D.A. \& Tesfaye, M. 2003. Plant improvement for tolerance to aluminum in acid soils - a review. Plant Cell, Tissue and Organ Culture 75:189-207.

Silitonga, T.S. 2008. Konservasi dan pengembangan sumberdaya genetik padi untuk kesejahteraan petani. Pekan Budaya Padi 2008 - KRKP. Badan Penelitian dan Pengembangan, Departemen Pertanian.

Suparto, H. 1999. Evaluasi ketenggangan padi gogo terhadap cekaman aluminium dan efisinesi penggunaan nitrogen. Tesis Pascasarjana. Bogor: Institut Pertanian Bogor.

Syakhril. 1997. Evaluasi Reaksi Varietas-varietas Padi gogo terhadap cekaman aluminium dan kekurangan nitrogen. Tesis Pascasarjana. Bogor: Institut Pertanian Bogor.

Wang, J.W. \& Kao, C.H. 2004. Reduction of Aluminum-inhibited Root growth of Rice Seedlings with Supplemental Calcium, Magnesium and Organic Acids. Crop, Env and Bioinf 1:191198

Zhang, X., Jessop, R.S. \& Ellison, F. 1999. Inheritance of root regrowth as indicator of apparent aluminium tolerance in triticale. Euphytica 108: 97-103.

Zhang, X., Garnet, T., Davies, K., Peck, D., Humphries, A. \& Auricht, G. 2004. Genetic evaluation and improvement of acid stress tolerance in lucerne breeding. http:// regional.org.au/au/asa/2004/poster/3/6/4/631 zhangxg.htm 